\title{
Case Law as an Authoritative Source of Customary Law: Piecemeal Recording of (Living) Customary Law?
}

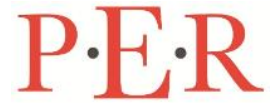

Pioneer in peer-reviewed, open access online law publications

Author

Christa Rautenbach

Affiliation

North-West University

South Africa

Email

Christa.Rautenbach@nwu.ac.za

Date Submission

1 October 2018

Date Revised

4 July 2019

Date Accepted

19 March 2019

Date published

12 December 2019

\section{Guest Editors}

Ms F Osman and Prof C Himonga

How to cite this article

Rautenbach C "Case Law as an Authoritative Source of Customary Law: Piecemeal Recording of

(Living) Customary Law?" PER /

PELJ 2019(22) - DOI

http://dx.doi.org/10.17159/17273781/2019/v22i0a7591

\section{Copyright}

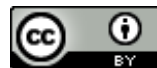

DOI

http://dx.doi.org/10.17159/17273781/2019/v22i0a7591

\begin{abstract}
This contribution deals with the question of whether a judgment from a mainstream court dealing with customary law can be regarded as authority and thus as a recording of a customary rule or rules. When a mainstream court develops customary law to promote constitutional values or strikes customary law down for want of constitutionality, it creates new rules which are written down but which can easily be changed when society brings it to court and convinces the court that the rule needs to be changed. It is my contention that case law is a binding source of law, including customary law, which must be followed until such time that it is either absorbed into legislation or amended by a subsequent decision in terms of the principle of stare decisis. It gives us some measure of assurance as to the law to be followed. The high number of customary law disputes taken to a court of law is confirmation that traditional communities are embracing the power of the courts to settle their disputes. The judgments of these courts inevitably become the origins of customary rules that they develop and can thus be regarded as piecemeal recording of (living) customary law.
\end{abstract}

\section{Keywords}

Customary law; sources of customary law; living customary law; judicial precedent 


\section{Introduction}

Scholarly discourses and judicial pronouncements on customary law have seen an unprecedented surge after receiving constitutional recognition in South Africa's first democratic constitution, and this trend continues. The transitional Constitution ${ }^{1}$ recognised indigenous law in $1994,{ }^{2}$ and ensured a prominent place for it in the final Constitution by promising that "[i]ndigenous law, like common law, shall be recognised and applied by the courts". ${ }^{3}$ The intention could not have been clearer: the common law and indigenous law were from now on to be treated alike.

The final Constitution does not refer to common law and indigenous law in the same breath, as did the transitional Constitution, but it also recognises that the institution of traditional leadership observes a "system of customary law", and compels the courts to apply customary law when applicable, though subject to the Constitution and any other legislation. ${ }^{4}$ It is generally accepted that the mandatory wording of the final Constitution elevated customary law to the same position as the common law ${ }^{5}$ and, although it is not always easy to treat them alike, that is exactly what the courts have been trying to do. So far three approaches can be identified. Firstly, in Bhe $v$ Magistrate, Khayelitsha, ${ }^{6}$ the Constitutional Court declined to develop the customary rule of male primogeniture to allow women to inherit and applied the common law of intestate succession, which treats beneficiaries equally, in its stead. Although this approach can be criticised, it is a good example

Christa Rautenbach. B luris (cum laude) LLB (cum laude) LLM LLD (NWU formerly the PU for CHE). Professor at the Faculty of Law, North-West University, Potchefstroom, South Africa. Email: christa.rautenbach@nwu.ac.za. I am indebted to the National Research Foundation and the Alexander von Humboldt Foundation for their generous funding. Errors and views remain for my own account.

1 Constitution of the Republic of South Africa Act 200 of 1993. It commenced on 27 April 1994 and was replaced by the final Constitution of the Republic of South Africa, 1996 (the Constitution) on 4 February 1997.

2 The 1993 Constitution did not provide for the direct recognition of customary law. Instead, it provided in $\mathrm{s} 181(1)$ for the recognition of a "traditional authority which observes a system of indigenous law", and in s 181(2) that "[i]ndigenous law shall be subject to regulation by law".

3 Principle XIII, Schedule 4 of the transitional Constitution. The transitional Constitution contained a set of principles in Schedule 4 that had to be taken into account when the final Constitution was drafted. In terms of $s$ 71(2) of the transitional Constitution, the Constitutional Court had to testify that all the provisions in the final text complied with these principles. This was done in In re: Certification of the Constitution of the Republic of South Africa, 1996199610 BCLR 1253 (CC).

4 See $\mathbf{2} 211$ of the Constitution. It is generally accepted that the terms "indigenous" and "customary" law are synonyms and that they should be treated as such.

5 Bennett Customary Law 39; Alexkor Ltd v Richtersveld Community 200312 BCLR 1301 (CC) para 51

6 Bhe v Magistrate, Khayelitsha 20051 SA 580 (CC). 
of instances where the common and customary law of succession have been fused to provide a better outcome for women and children other than the first born male. ${ }^{7}$

By contrast, the second approach confirms the prerogative of a community to develop its own rules. In Shilubana $v$ Nwamitwa, ${ }^{8}$ the Constitutional Court sanctioned the development of a customary rule favouring males as traditional leaders to allow a female to become the traditional leader at the request of the community.

In the third example, the Constitutional Court in $M M v M N^{\rho}$ developed a Tsonga custom to make it compulsory for a husband to obtain the permission of his wife to enter into a consecutive marriage.

Although the three approaches are totally different, they have one thing in common - the proceedings were initiated by people who follow customary law. It may be argued that the fact that the people themselves are bringing their disputes to the courts to resolve is an indication that the judiciary can produce case law as an authoritative source of developing customary law.

In accordance with the principle of stare decisis (to stand by precedents), the cases mentioned in this contribution (and the many others not dealt with) provide a measure of certainty to people and the judiciary. They are judicial precedent and thus binding on everyone and everything. The principle of stare decisis provides "[c]ertainty, predictability, reliability, equality, uniformity, [and] convenience"10 and is, according to the Constitutional Court, a "manifestation of the rule of law itself, which is in turn a founding value of our Constitution"."11

In addition to the principle of stare decisis, the courts have been constitutionally endowed with the power to develop the common and customary law under certain circumstances, though it has not been done consistently. Section $8(3)$ of the Constitution - notice the absence of customary law - stipulates:

When applying a provision of the Bill of Rights to a natural or juristic person in terms of subsection (2), a court -

(a) in order to give effect to a right in the Bill, must apply, or if necessary develop, the common law to the extent that legislation does not give effect to that right; and

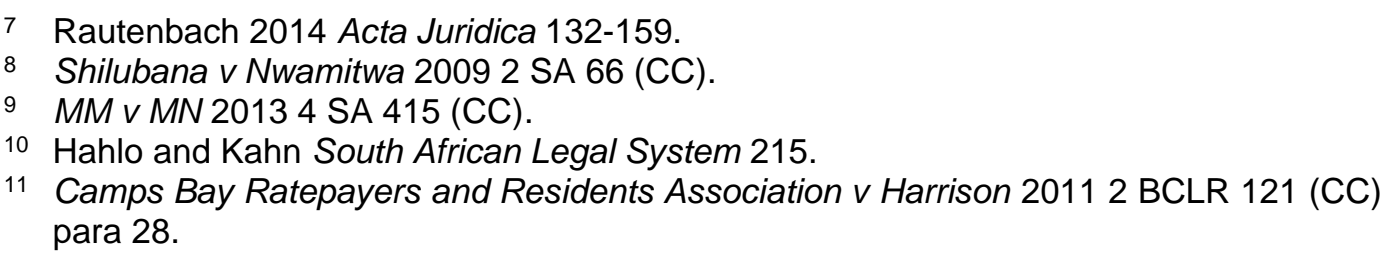


(b) may develop rules of the common law to limit the right, provided that the limitation is in accordance with section $36(1){ }^{12}$

In addition, the interpretation clause, section 39(2), includes customary law and reads:

When interpreting any legislation, and when developing the common law or customary law, every court, tribunal or forum must promote the spirit, purport and objects of the Bill of Rights.

Section 173 confirms the "inherent power" of the higher courts to develop the common law that they had in terms of the common law, but customary law is not mentioned. It stipulates: ${ }^{13}$

\section{The Constitutional Court, Supreme Court of Appeal and High Courts have the inherent power to protect and regulate their own process, and to develop the common law, taking into account the interests of justice.}

The exclusion of customary law is intriguing. Does it mean that the higher courts can develop customary law only in terms of section 39(2) to "promote the spirit, purport and objects of the Bill of Rights" and not in terms of section 173 ? The courts always had an inherent jurisdiction to fill gaps in the common law "to meet the needs of a changing society". ${ }^{14}$ This is referred to as "judicial-law making", ${ }^{15}$ and this is probably what the inherent power in section 173 also refers to. The Constitutional Court has confirmed that section 173 should be used sparingly; it cannot be used to simply ignore a statute or to side-step a statute by "resorting to the common law". ${ }^{16}$ Recently, in Mokone $v$ Tassos Properties, ${ }^{17}$ it held that section 173 could also be employed to develop the common law outside the ambit of section 39(2).

The courts, however, never had a similar power to fill gaps in the customary law, and its (deliberate?) exclusion from section 173 could mean that they still do not have such a power. Nevertheless, it has often been said that the

12 Emphasis added. Subs 2 reads: "A provision of the Bill of Rights binds a natural or a juristic person if, and to the extent that, it is applicable, taking into account the nature of the right and the nature of any duty imposed by the right."

13 Emphasis added.

14 Amod v Multilateral Motor Vehicle Accident Fund 19984 SA 753 (CC) para 22.

15 Hahlo and Kahn South African Legal System 304-305. Also see the earlier dicta that the authors cite to illustrate the courts' power to create new law.

16 See Phillips v National Director of Public Prosecution 20062 BCLR 274 (CC) paras 4652 and the cases cited. In $S$ v Thunzi 201010 BCLR 983 (CC) para 51 the Court conceded that $\mathrm{s} 173$ could also be used to do more than just fill legislative gaps if the interest of justice required it.

17 Mokone v Tassos Properties 20171 BCLR 1261 (CC) para 41. 
provisions of the Constitution must be read as a whole, and in $S v$ Lubisi $^{18}$ the Court pointed out that section 173 must be read with other sections of the Constitution, including section 39(2), to interpret the inherent power of the court to develop the common law. To date, the need has not arisen to interpret the application of section 173 on customary law, but I can imagine that it could be relevant to fill a gap in official customary law. I cannot foresee how it could be applied if the gap in question has arisen in the context of living customary law.

Historically, customary law has been orally transmitted. Although parts of it have now been recorded in legislation, case law and textbooks, it is essentially unwritten. ${ }^{19}$ As explained in Alexkor Ltd $v$ Richtersveld Community: ${ }^{20}$

In applying indigenous law, it is important to bear in mind that, unlike common law, indigenous law is not written. It is a system of law that was known to the community, practised and passed on from generation to generation. It is a system of law that has its own values and norms. Throughout its history it has evolved and developed to meet the changing needs of the community. And it will continue to evolve within the context of its values and norms consistently with the Constitution.

True to the modern tradition of documentation, ${ }^{21}$ many customary laws have been reduced to writing by scholars, and though these sources are still referred to in the courts, it has been reasoned that they must be used with caution, because they were viewed from a different context - the common law - and might not reflect the true position. ${ }^{22}$ At least three types of customary law are identified: official customary law, which is found in statutes, case law and authoritative textbooks; academic teachings; and living customary law. ${ }^{23}$ The idea of living customary law that has not been reduced to writing is not novel. Even before the constitutional recognition of customary law, the Appellate Division in Sigcau v Sigcau ${ }^{24}$ pointed out that Pondo law and custom is mostly a body of unwritten law, and that even the rules that have been recorded in reports or cases are merely opinions and

18 S v Lubisi 20039 BCLR 1041 (T) 1051. As explained by the Court: "Although the powers granted to the court in terms of section 173 of the Constitution still have to be exercised with caution and circumspection, the Constitution has broadened the scope for judicial activism where such appears to be in the interest of justice (at 1052)."

19 Bennett Customary Law 2.

20 Alexkor Ltd v Richtersveld Community 200312 BCLR 1301 (CC) para 53. Footnotes omitted.

21 Contrary to the written tradition of the Romans, other European tribes had unwritten laws. Madden 2013 Widener LJ 757-828.

22 Alexkor Ltd v Richtersveld Community 200312 BCLR 1301 (CC) para 54; Shilubana v Nwamitwa 20092 SA 66 (CC) para 44.

23 Bhe v Magistrate, Khayelitsha 20051 SA 580 (CC) para 152.

24 Sigcau v Sigcau 1944 AD 76. 
statements of "what someone at some time said the custom was". The only way a court could determine what the customary rule entailed was to "hear evidence as to that custom from those best qualified to give it and to decide the dispute in accordance with such evidence as appears in the circumstances to be most probably correct".

However, locating the true content of a customary rule falls outside the scope of my paper. What I am concerned with is the question of whether a judgment dealing with customary law can be regarded as authority and thus as a documentation of a customary rule or rules. Take the $M M v M N^{25}$ case, for example; would the fact that the Constitutional Court developed Tsonga law to require a husband to obtain his wife's permission to marry a subsequent wife be respected and followed by the community? In other words, could a customary rule that was developed by a court be regarded as an authoritative source or origin of the rule? At this point, I have to concede that this is probably a question which calls for extensive fieldwork; however, one might argue that it should because judgments are another way of creating law.

\section{Contextualising the issues}

Before I continue sharing my ideas on case law as an authoritative source of customary law, let me briefly explain what some of the concepts mean within the context of this paper.

Let us commence with the meaning of law. The quest to find a universally accepted definition of law has been keeping legal theorists busy for a very long time, and will continue to do so. ${ }^{26}$ Our understanding of law is premised on different worldviews, paradigms and contexts. ${ }^{27}$ For the purpose of my discussion, I prefer to take the easy way out by proposing a functional approach. Considering that one of the functions of law is to "ensure order in the relationships and interactions among people ${ }^{28}$ and between people and

MM v MN 20134 SA 415 (CC).

26 Donlan and Urscheler Concepts of Law (2014) contains a collection of chapters on differing viewpoints regarding the meaning of law.

27 Humbey et al Introduction to Law 2. Donlan and Urscheler Concepts of Law (2016) 118 discusses the effect of context, across both time and space, on the meaning of law. They propose a multidisciplinary approach to the understanding of law that does not impose Western standards but recognises that there is a diversity of perspectives which does not always involve state institutions. Such an approach would include cultural perspectives such as customary law.

28 In this definition, the word "people" should be given a broad meaning to include the state as well. 
things in a society", law can simply be defined as normative rules 29 "made by society for society". ${ }^{30}$ As aptly put by Hahlo and Kahn in their iconic book on the making of the South African legal system: ${ }^{31}$

Law is the warp and woof of social life, and so far from being concerned with a narrowly circumscribed area, is all pervasive. It is not only concerned with the pathology of society, but with its physiology as well.

This idea of law is premised on the social contract theory of Hobbes - there is a social contract in terms of which the people authorise their leaders to make laws to create order within society. ${ }^{32}$

Some may disapprove of my simplistic view of what law is, but taking the view that law is "an attribute of human life that appears when people group or associate themselves into a society" 33 might be useful to explain why we have a South African legal order where different legal systems regulate the relationships and interactions between the people and/or things on different levels. It provides some explanation, besides historical events, for the presence of legal pluralism, a social and legal phenomenon, in South Africa. ${ }^{34}$

Although legal pluralism is an equally fluid concept, it basically refers to the existence of multiple legal systems within one geographical area. ${ }^{35}$ In South

29 I am well aware that by using the term "normative", I step right into another minefield, namely the distinction (if there is one) between law and other social norms based on, for example, culture or religion. During my law student days, I understood the difference between a legal and a social norm simply to be the following: a legal norm is a mandatory rule of social behaviour established by a state organ while a social norm is a group-held belief about how members of a community should (not must) behave in a given situation. Nowadays, I have come to realise that the solution is not as simple as that. In a pluralistic legal system such as in South Africa, where two seemingly incompatible legal systems exist side by side, the one well-documented and developed and the other essentially consisting of oral accounts of social practices of traditional communities, there are no clear lines between the "legal" and "social" of norms. Furthermore, I have come to realise that the involvement of a state organ is not essential in establishing what is regarded as law. See Rautenbach "Thinking about Norms in Pluralistic Societies" 110-113.

30 Humbey et al Introduction to Law 1.

31 Hahlo and Kahn South African Legal System 1.

32 Hobbes Elements of Law ch 9.

33 Humbey et al Introduction to Law 1.

34 Legal pluralism is regarded as both a social and a legal phenomenon. See Desmet "Legal Pluralism and International Human Rights Law" 41.

35 Griffiths $1986 \mathrm{~J}$ Legal Plur 1, 13-17. He distinguishes between deep and weak legal pluralism. Deep legal pluralism, according to him, is based on the ideology of legal centralism. In other words, there must be state recognition. South African customary law and common law are examples of recognised legal systems. Weak legal pluralism, on the other hand, concedes that other or opposing norms may exist and exert some authority on peoples' social lives. The state may even play a subordinate role to the regulation implemented by an informal authority. Islamic law is an example of such a system that is not recognised but is followed by the adherents to Islam nonetheless. 
Africa, for example, the common law exists alongside the customary law. The plurality of the South African legal system - the product of more than 300 years of European settlement, colonialism and apartheid - is undisputed. Historical events are important to understand changes or developments in law and society. As pointed out by Watson, a "theory of the relationship between law and society must rest ... on detailed knowledge of the history of individual legal systems". ${ }^{36}$ Although history might explain why law is what it is, legal change is inevitable and customary law would also have changed, though we can only speculate how it would have changed, were it not for Western contact. ${ }^{37}$

Customary law today is not a unified system of law; it has never been. It consists of diverse legal systems made up of the rules of the various communities living in rural areas. Even though those rules are grounded in the community, they are regarded as binding. Hamnett ${ }^{38}$ describes customary law as "a set of norms which the actors in a social situation abstract from practice and which they invest with binding authority". Also, Bennett ${ }^{39}$ describes customary law as a legal system that "derives from social practices that the community concerned accepts as obligatory". South African legislation recognises these social features of customary law. For example, the Recognition of Customary Marriages Act 120 of 1998 defines "customary law" as "the customs and usages traditionally observed among the indigenous African peoples of South Africa and which form part of the culture of those peoples". 40

Most scholarly literature refers to the South African legal system as a dual system of law, consisting of the common law (predominantly a RomanDutch and English law mix) and customary law (the indigenous laws of traditional communities). I have done the same in earlier writings. ${ }^{41}$ However, it is perhaps time to stop focusing on this duality and to zoom in on the oneness of the South African legal system instead. Let me explain what I mean. South African law is to all intents and purposes an uncodified legal system, both common and customary law. Despite the existence of piecemeal legislation regulating certain aspects of both common and customary law, the South African legal system has not been "systematically recorded in a comprehensive code which serves as primary source of its

\footnotetext{
Watson 1983 U Pa L Rev 1121, 1122.

"Western" in this context refers to the Dutch and English colonial influences.

Hamnett Chieftainship and Legitimacy 14.

Bennett Customary Law 1.

40 See $\mathrm{s} 1$ of the Recognition of Customary Marriages Act 120 of 1998 (the Recognition Act).

41 Rautenbach "Contribution of the Courts" 225-244.
} 
origin and knowledge about it". ${ }^{42}$ As there is no primary source (or code) of South African law, we need to consult a wide collection of sources to find the law. ${ }^{43}$ These sources comprise the Constitution in a supreme position, ${ }^{44}$ also legislation, ${ }^{45}$ judicial precedent, ${ }^{46}$ international and foreign law, ${ }^{47}$ common law (old-authority), ${ }^{48}$ custom, ${ }^{49}$ customary law, ${ }^{50}$ and finally modern scholarly sources. ${ }^{51}$ The Constitution seems to treat both common and customary law as sources. One example is the interpretation clause, which recognises the existence of rights and freedoms outside the text of the Constitution, where they "are recognised or conferred by common law,

42 Du Plessis Introduction to Law 75.

43 According to Hahlo and Kahn South African Legal System 139-140 sources may be regarded historically (depending on their historical roots) or analytically, depending on the theoretical stance of the legal scholar doing the analysis.

44 The Constitution announces its supremacy in s 2: "This Constitution is the supreme law of the Republic; law or conduct inconsistent with it is invalid, and the obligations imposed by it must be fulfilled." Emphasis added.

45 Hahlo and Kahn South African Legal System ch 6 deals with legislation as a source of law. Though their discussion is outdated, it remains relevant.

46 Judicial precedent refers to new legal rules that are developed by the courts. See Hahlo and Kahn South African Legal System chs 7 and 9 for a discussion of judicial precedent and judicial law making which remains relevant. Ss 8 and 39 of the Constitution confirm the developmental function of the courts with regard to the common and customary law.

47 Section 39 of the Constitution confirms the important role of international and foreign law during judicial interpretation of the Bill of Rights. Ss 231-233 of the Constitution also regulate the position with regard to international agreements and customary international law. However, international law and foreign law are not binding sources and the courts need only to "consider" them, not to follow them.

48 In the absence of legislation and case law, the law of old Roman-Dutch law authorities found in the $17^{\text {th }}$ and $18^{\text {th }}$ century sources of the law of Holland is applicable. However, nowadays, these sources are rarely consulted. Most of the common law rules have been stated in case law or modern textbooks. See Hahlo and Kahn South African Legal System 303; Humbey et al Introduction to Law 144.

49 Custom in this context refers to the unwritten customs in society that obtained authority over a period of time. However, in order for a custom to obtain legal status, it has to comply with certain requirements and be affirmed by a court of law. The well-known case of Van Breda $v$ Jacobs 1921 AD 330 serves as confirmation of the requirements which must be met. Also see Hahlo and Kahn South African Legal System 302-303; Humbey et al Introduction to Law 145. In Shilubana v Nwamitwa 20092 SA 66 (CC) para 54, the Constitutional Court pointed out that there are important differences between custom and customary law. The former refers to practices that could fill normative gaps in the common law. This means that custom is not an "original source of law capable of independent development" but simply an "accessory source". Conversely, customary law is an independent source of law which can develop on its own.

50 As already alluded to, customary law is essentially the unwritten customs of traditional African communities, but it has not remained unscathed over the years. It has been supplemented, amended, developed or superseded by progressive governments, and by its coming into contact with other communities and modernity. Olivier "Indigenous Law" 1.

51 Depending on the reputation of the authors, these sources are secondary sources of the law and have only persuasive value in the courts. 
customary law or legislation". ${ }^{2}$ Though the Constitution does not say it in so many words, it regards the common and customary laws as sources of those rights and freedoms which might exist outside the constitutional text.

Viewed this way, both common law and customary law are, at least theoretically, treated the same - they are both sources of South African law. Customary law is an independent source of South African law, just as common law is. As pointed out in Alexkor Ltd $v$ Richtersveld Community: ${ }^{53}$

\begin{abstract}
... the Constitution acknowledges the originality and distinctiveness of indigenous law as an independent source of norms within the legal system. At the same time the Constitution, while giving force to indigenous law, makes it clear that such law is subject to the Constitution and has to be interpreted in the light of its values. Furthermore, like the common law, indigenous law is subject to any legislation, consistent with the Constitution, that specifically deals with it. In the result, indigenous law feeds into, nourishes, fuses with and becomes part of the amalgam of South African law.
\end{abstract}

Taking the view that both common and customary law are sources of law, forming part of the "amalgam of South African law", also explains why those two apparently "independent" sources of law are often interlinked. After all, they have co-existed for many years in one geographical area, and it would be impossible for them to escape cross-pollination. Although most of those influences have been subtle, there are a few obvious examples, such as the modification of the common and customary law of succession. ${ }^{54}$ Therefore, our quest to keep common and customary law apart at all costs seems all the more perplexing. Maitland wrote the following on the quest to classify legal rules into neat compartments: ${ }^{55}$

But do not get into the way of thinking of law as consisting of a number of independent compartments ... . No, law is a body, a living body, every member of which is connected with and depends upon every other member. ... Science deals with the body as a whole, and with every part of it as related to the whole. ... [N]o good comes of refusing to see the truth, and the truth is that all parts of our law are very closely related to each other .... .

Insisting that South African law is a unity made up of a diversity of "independent sources", all linked together by a supreme Constitution, is in line with the preamble's aspirations of creating a country that is "united in our diversity". This being said, we need to acknowledge that there are fundamental differences in these two sources of South African law,

52 See s 39(3) of the Constitution.

53 Alexkor Ltd v Richtersveld Community 200312 BCLR 1301 (CC) para 51. Footnotes omitted, and emphasis added.

54 See Rautenbach 2008 J Comp L 119-132.

55 Although he refers to the branches of law such as administrative law, criminal law, family law, etc, the same argument is valid for the diverse legal systems in one geographical area. See Maitland Constitutional History of England 539. 
especially with regard to the origins of the legal rules. Apart from common law custom (an unwritten source until affirmed by the court), ${ }^{56}$ the other sources of South African law are written down, while customary law is mostly unwritten. Orality is thus the most striking feature of original customary law. Bennett points out that this feature has a number of consequences. ${ }^{57}$ Firstly, customary law is ever-changing and is or at least is believed to be "always up to date". Secondly, the "law" in customary law is not always easy to distinguish from mere custom. Lastly, there is no involvement of people or other entities, such as a legislature, to make and document the law. ${ }^{58}$ However, the orality of customary law rules does not make them less binding on community members and therefore less "law" than other written law. ${ }^{59}$

Does the orality of customary law make it impossible for case law to be regarded as authority for a customary law rule, because it has not originated from society but from a court of law? This question is closely related to my contention in the introduction that because people living under a system of customary law themselves are bringing their disputes to mainstream courts to resolve, it indicates that these courts can produce case law as an authoritative source of customary law.

\section{Case law as an authoritative source of customary law}

As already alluded to, for a source to be authoritative or binding, it must be regarded as such by society. How do we find those obligatory rules derived from social practices or the "customs and usages traditionally observed"? In other words, what are the sources or point of origin of customary law? Most legal scholars claim that the point of law is recognition by society, and that legal rules must be formulated by those people and institutions that society has chosen for this purpose. ${ }^{60}$ Hamnett writes that "customary law

56 Referring to custom as acknowledged in Van Breda $v$ Jacobs 1921 AD 330.

57 Bennett Customary Law 2.

58 Bennett Customary Law 2. However, one may argue that a traditional authority fulfils the role of a legislature in a customary law setting.

59 Licht 2008 RLE 715-750.

60 Humbey et al Introduction to Law 123. Some scholars argue that law's point must be found in the universal principles of morality and justice. This is the so-called "natural law" theory. There are many variations of this theory, but it essentially holds that law is "necessarily a rational standard for conduct"; it does not depend on human intervention but exists because it is natural, universal and a necessary consequence of human nature. Traditionally, a sharp contrast is drawn between natural law and legal positivism. In contrast to natural law, legal positivism regards law as a "socially recognised standard". See in general, Crowe 2016 Philosophy Compass 91-101 for a discussion of the natural law theories. 
emerges from what people believe they ought to do, rather than from what a class of legal specialists consider they should do or believe". 61

A cursory search of the term "customary law" in the online database, MyLexisNexis, ${ }^{62}$ indicates that 150 judgments dealing with some or other customary law issue have been published since 1996. That means an average of almost 9 cases per year. However, is it highly probable that the actual number is much higher because many decisions are not published, and without empirical research of some kind, it would be difficult to know the exact number of customary law disputes that have been heard by the mainstream courts. At least three types of disputes may be distinguished, namely: disputes between individuals, ${ }^{63}$ between individuals and traditional leaders and/or authorities ${ }^{64}$ and between traditional leaders and/or authorities and government. ${ }^{65}$

The great number of published cases on customary law illustrates two points I should like to make. Firstly, it demonstrates that those institutions and members of traditional communities who have the means to do so or who have access to legal aid prefer to settle their disputes in mainstream courts instead of using traditional dispute mechanisms. A culture of litigation sparked by the Constitution seems to be developing in traditional communities. Institutions and members of traditional communities are increasingly turning to the courts to litigate their issues. What does this mean, other than that they obviously trust the judiciary to solve their

61 Hamnett Chieftainship and Legitimacy 10.

62 LexisNexis 2018 http://www.mylexisnexis.co.za/ (subscription needed).

63 The great bulk of cases falls in this category, and most of them deal with family disputes in a human rights context. A well-known example is Bhe $v$ Magistrate, Khayelitsha 2005 1 SA 580 (CC), where the constitutionality of the customary rule of male primogeniture was successfully challenged.

64 For example, in Bangindawo $v$ Head of the Nyanda Regional Authority; Hlantlalala $v$ Head of the Western Tembuland Regional Authority 19983 BCLR 314 (Tk) two applications were brought before the Transkei High Court. The applicant in the one case disputed the jurisdiction of the Nyanda Regional Authority over him, and the applicant in the other case disputed the jurisdiction of the Western Tembuland Regional Authority. They based their cases on the fact that the former Transkei had been re-incorporated into South Africa, that they were no longer citizens of Transkei but of South Africa, and therefore the courts which were established for the Transkei no longer had jurisdiction over them. The court of appeal held, however, that the Constitution made provision for the continuance of legislation in the former homelands and that the regional courts remained in operation for the time being. Shortly after the judgment had been delivered, the courts were discontinued. See Rautenbach and Bekker Introduction to Legal Pluralism 245.

65 For example, in Sepadi v Premier of Limpopo Provincial Government 2016 JOL 34328 (GP) the applicant averred that he was a recognised headman and sought an order declaring the termination of his salary as unlawful. The Court held that he had the onus of producing a certificate as recognition and because he had not, the application was dismissed. 
disputes? It would not be outrageous to argue that they regard case law as an authoritative source of customary law. Secondly, one could argue that their insistence on settling their disputes in mainstream courts instead of utilising traditional dispute mechanisms shows that they no longer trust these traditional methods to deliver fair or binding outcomes. This could mean that their stance on Western justice has undergone a fundamental change. It is highly probable that they accept it as authoritative and thus binding.

Let me illustrate with an example. During the lifetime of Masewa Netshituka, a businessman from Thohoyandou, he married five wives. Three of the marriages were customary (Tshinakaho, Masindi and Diana) and two were civil marriages (Martha and Joyce). When he died on 4 January 2008, he was survived by Tshinakaho, Diana and Joyce and a number of children born from these marriages. Masindi had already died in 1995, and he had previously divorced Martha in 1984. In accordance with the consequences of a civil marriage, Masewa's marriage to Joyce was in community of property and she was legally entitled to half of Masewa's estate. His customary law wives were less fortunate. In terms of Venda customary law, they had no ownership or control over the marital property and, except for the bequests he made to them in his will, they would not have been entitled to any of his property or that which fell into Joyce's half of the estate. In addition, the deceased had executed a will in which he had made certain bequests regarding his half share in the joint estate. ${ }^{66}$ Tshinakaho and some of the deceased's children were unhappy with their exclusion from the deceased's estate and they began with litigation in all earnest.

In Netshituka $v$ Netshituka, ${ }^{67}$ they launched an application for an order declaring the marriage between the deceased and Joyce null and void, and the will invalid. ${ }^{68}$ Unfortunately, Tshinakaho and Diana had passed away before the judgment was delivered, three years after the death of the deceased. Five judges of the Supreme Court of Appeal agreed that the marriage between the deceased and Joyce was a nullity because he was not allowed to conclude a civil marriage while he was still involved in customary marriages, but they refused to declare the will invalid.

The children had succeeded in having the deceased's civil marriage with Joyce declared a nullity, but they did not take lightly their defeat in respect of the validity of the will. They instituted proceedings again in the High Court

66 He bequeathed his half share of the joint estate to his wives, including Joyce, and all his children. See Ramuhovhi v President of the RSA 20166 SA 210 (LT) para 9.

67 Netshituka $v$ Netshituka 20115 SA 453 (SCA).

68 The validity of the will also came under attack, but the attack did not succeed. 
of Thohoyandou in Ramuhovhi $v$ President of the RSA. ${ }^{69}$ This time their strategy was to attack the constitutionality of section $7(1)$ of the Recognition Act. This provision stipulates that "[t]he proprietary consequences of a customary marriage entered into before the commencement of this Act continue to be governed by customary law" ${ }^{70}$ As already explained, Venda law excludes wives from the ownership and control of marital property, and they were thus effectively barred from the ownership of the deceased's estate. Joyce, the discarded civil law ${ }^{71}$ wife, was part of the proceedings again. She also contended that section 7(1) was invalid and argued that, though her civil marriage to the deceased had been declared a nullity, she and the deceased had also entered into a customary marriage in 1996, and she was for all technical purposes also a customary law wife of the deceased who must share in the property if section 7(1) were to be declared unconstitutional. ${ }^{72}$ After a constitutional analysis, the High Court found that section 7(1) was indeed discriminatory and thus invalid. ${ }^{73}$ In addition, customary law had to be developed to allow women in polygynous marriages concluded before the Recognition Act to enjoy equal rights in and over matrimonial property. The order was referred to the Constitutional Court for confirmation. ${ }^{74}$

In Ramuhovhi $v$ President of the $R S A,{ }^{75}$ the Constitutional Court confirmed the High Court's declaration of invalidity. The order of invalidity was suspended for 24 months (to 30 November 2019) to afford parliament the opportunity to amend the legislation to correct the invalid provision. Until such amendment has been made, a husband and all his wives have joint and equal ownership over joint property. ${ }^{76}$

An interesting development occurred while the case was being heard in the Constitutional Court. An application for leave to intervene was made by woman who was a second wife in another polygynous marriage. When her

69 Ramuhovhi v President of the RSA 20166 SA 210 (LT).

70 Emphasis added.

71 The criticisms raised against this judgment are not relevant for this discussion, but it has been argued that the outcome discards the patrimonial and human rights of a civil law wife in favour of the customary law wives. See Buchner-Eveleigh 2012 De Jure 604.

72 Ramuhovhi v President of the RSA 20166 SA 210 (LT) para 29.

73 Ramuhovhi v President of the RSA 20166 SA 210 (LT) para 75.

74 See Ramuhovhi v President of the RSA 20166 SA 210 (LT) para 76 for the final order of the Court.

75 Ramuhovhiv President of the RSA 20182 BCLR 217 (CC). The judgment was delivered on 30 November 2017.

76 In the case of house property, the husband and the wife of the house concerned jointly have control over the property and in the case of family property, the husband and all the wives jointly have control over the property. Personal property, however, remains the property of the spouses, 
husband died, she had discovered that he had had a will in which he had stated that he was unmarried and in which he had bequeathed their family home to his eldest son by his first wife, who wanted to evict her when he learned of his windfall. ${ }^{77}$ The second wife intended to institute proceedings in another court with regard to her proprietary rights but had an interest in how the Constitutional Court in Ramuhovhi v President of the RSA intended framing the order of retrospectivity. Therefore, it was important for her that the Court made an order that protects estates which have not yet been wound up. The Court agreed with her contentions and she was granted leave to intervene. The order that the Court in Ramuhovhi $v$ President of the $R S A$ eventually made with regard to retrospectivity was eventually in her favour. It ordered that the declaration of invalidity of section $7(1)$ of the Recognition Act was retrospective except where a deceased estate had already been wound up or the transfer of marital property had been finalised. The situation would be different, however, if the transferee of the marital property were, at the time of the transfer, aware that the property was subject to a legal challenge. ${ }^{78}$ This caveat should act as a warning for anyone who wants to do another family member over by transferring the marital property despite it being subject to a dispute.

The facts of these cases demonstrate the point I wish to make. Scholarly discourses on customary law usually focus on the differences between common and customary law, but it seems as if society has long since accepted the authority of the mainstream courts. The Netshituka family gave the impression that they have followed a traditional lifestyle in their private lives, but nevertheless approached the courts to solve their family disputes.

The idea that the binding authority of customary law comes from society seems to be irreconcilable with the idea of precedent as a source of customary law. However, considering that society brings its customary law disputes to the courts, as illustrated by this example and the many others, the inference can be drawn that case law is indeed regarded, at least by the litigants, as an authoritative source of customary law. It is also true that the fact that one section of the community who can afford to bring litigation all the way up to precedent-making courts, provides no guarantee that the rest of the community whose customary law was the subject of adjudication would consider themselves bound by the decision which constitutes the precedent. Other dangers also lurk in the background. The possibility exists that this source of law (case law) has become skewed in favour of those who can afford to litigate, creating the possibility that affluent members of

77 See Ramuhovhi v President of the RSA 20182 BCLR 217 (CC) paras 14-29.

78 Ramuhovhi v President of the RSA 20182 BCLR 217 (CC) para 71, at points 7 and 8. 
the communities define (indirectly through the litigation process) the law for the rest of the community. Although this is a real danger, there are many examples where poor litigants have been able to change the direction of customary law through the assistance of non-profit organisations, such as the Women's Legal Centre, which provides free legal advice and support to particularly women living under a system of customary law. ${ }^{79}$ Therefore, this risk should not prevent courts from involving themselves in the creation of customary rules where needed.

\section{Conclusion}

The sources of South African law, an uncodified diverse legal system, are manifold. They consist of common law, customary law, legislation, judgments, custom, the law of old authorities and other authentic sources. The origins of the legal rules found in these sources may differ considerably. The common law is a mixture of Roman-Dutch law and English law. Customary law, at least in its living form, consists of binding rules followed in traditional communities, and so on.

The sources are interconnected, however. Together they form a living body of law called South African law which is constantly evolving as society is changing. Traditional communities trust the mainstream courts to solve their disputes. They challenge rules that are unconstitutional. Traditional authorities develop their rules and then ask the courts to endorse those changes. The list goes on. Surely these actions must all be an indication of acceptance of the authority of the courts by traditional communities and their leaders?

When a mainstream court develops customary law to promote constitutional values or strikes customary law down for want of constitutionality, it creates new rules which are written down but which can easily be changed when society brings it to court and convinces the court that the rule needs to be changed. It is thus my contention that case law is a binding source of law, including customary law, which must be followed until such time that it is either absorbed into legislation or amended by a subsequent decision in terms of the principle of stare decisis. It gives us some measure of assurance as to the law to be followed.

The high number of customary law disputes taken to a court of law is confirmation of the fact that traditional communities are embracing the power of the courts to settle their disputes. The judgments of these courts

79 See the official website of the Centre where a number of those cases are listed Women's Legal Centre 2018 http://www.wlce.co.za/about-us/. 
inevitably become the origins of customary rules that they develop and can thus be regarded as piecemeal recording of (living) customary law.

I have to concede, however, that my views on this matter are tainted by the fact that I am a typical lawyer. It is inconceivable to me that customary law can continue to exist without the influence of precedent. On the one hand, the ossification of customary law by precedent is a reality but on the other hand, a precedent could be reversed or developed when there is a change in the community. To put it differently, when a court develops customary law through precedent, it creates a written rule of customary law but one which is changeable as the circumstances change or when a new precedent setting judgment is delivered.

Finally, as I have already alluded to, only empirical research would be able to tell us if case law is indeed regarded as an authoritative source of customary law by community members. However, it would be a conundrum to argue that they do not while they seem to trust the mainstream courts enough to solve their customary law disputes.

\section{Bibliography}

\section{Literature}

Bennett Customary Law

Bennett TW Customary Law in South Africa (Juta Lansdowne 2004)

Buchner-Eveleigh 2012 De Jure

Buchner-Eveleigh M "Netshituka v Netshituka 2011 (5) SA 453: Revival of a Customary Marriage Previously Dissolved by a Subsequent Civil Marriage" 2012 De Jure 596-605

Crowe 2016 Philosophy Compass

Crowe J "Natural Law Theories" 2016 Philosophy Compass 91-101

Desmet "Legal Pluralism and International Human Rights Law"

Desmet E "Legal Pluralism and International Human Rights Law" in Corradi G, Brems E and Goodale M (eds) Human Rights Encounter Legal Pluralism: Normative and Empirical Approaches (Hart Oxford 2017) 41-54

Donlan and Urscheler Concepts of Law (2014)

Donlan SP and Urscheler LH Concepts of Law: Comparative, Jurisprudential and Social Science Perspectives (Ashgate Farnham 2014)

Donlan and Urscheler Concepts of Law (2016)

Donlan SP and Urscheler LH Concepts of Law: Comparative, Jurisprudential, and Social Science Perspectives (Routledge Oxon 2016) 
Du Plessis Introduction to Law

Du Plessis LM An Introduction to Law $3^{\text {rd }}$ ed (Juta Cape Town 1992)

Griffiths 1986 J Legal Plur

Griffiths J "What is Legal Pluralism?" 1986 J Legal Plur 1-55

Hahlo and Kahn South African Legal System

Hahlo HR and Kahn E The South African Legal System and its Background (Juta Cape Town 1968)

Hamnett Chieftainship and Legitimacy

Hamnett I Chieftainship and Legitimacy: Anthropological Study of Executive Law in Lesotho (London Routledge 1975)

Hobbes Elements of Law

Hobbes T The Elements of Law: Natural and Politic (Cambridge University Press 1928)

Humbey et al Introduction to Law

Humbey T et al Introduction to Law and Legal Skills in South Africa (Oxford University Press Cape Town 2012)

Licht 2008 RLE

Licht AN "Social Norms and the Law: Why Peoples Obey the Law" 2008 RLE 715-750

Madden 2013 Widener LJ

Madden MS "Paths of Western Law after Justinian" 2013 Widener LJ 757828

Maitland Constitutional History of England

Maitland FW The Constitutional History of England: A Course of Lectures Delivered (The Law Book Exchange New Jersey 2001)

Olivier "Indigenous Law"

Olivier NJJ "Indigenous Law" in Joubert WA et al (eds) Law of South Africa $2^{\text {nd }}$ ed (LexisNexis Online 2009)

Rautenbach 2008 J Comp L

Rautenbach C "South African Common and Customary Law of Intestate Succession: A Question of Harmonisation, Integration or Abolition" $2008 \mathrm{~J}$ Comp L 119-132

Rautenbach 2014 Acta Juridica Rautenbach C "A Few Comments on the (Possible) Revival of the Customary Law Rule of Male Primogeniture: Can the Common-Law 
Principle of Freedom of Testation Come to Its Rescue?" 2014 Acta Juridica 132-159

Rautenbach "Contribution of the Courts"

Rautenbach C "The Contribution of the Courts in the Integration of Muslim Law into the Mixed Fabric of South African Law" in Mattar MY, Palmer V and Koppel S (eds) Mixed Legal Systems, East and West (Ashgate Farnham 2015) 225-244

Rautenbach "Thinking about Norms in Pluralistic Societies"

Rautenbach C "Thinking about Norms in Pluralistic Societies: Blurred Lines Between the 'Legal' and the 'Social' of Pluralist Normative Order" in Albarian A and Moréteau $O$ (eds) Le droit comparé et... / Comparative Law and... (University Press d'Aix-Marseille 2015) 107-115

Rautenbach and Bekker Introduction to Legal Pluralism

Rautenbach C and Bekker JC Introduction to Legal Pluralism in South Africa $4^{\text {th }}$ ed (LexisNexis Durban 2014)

Watson 1983 U Pa L Rev

Watson A "Legal Change: Sources of Law and Legal Culture" 1983 U Pa L Rev 1121-1157

\section{Case law}

Alexkor Ltd v Richtersveld Community 200312 BCLR 1301 (CC)

Amod v Multilateral Motor Vehicle Accident Fund 19984 SA 753 (CC)

Bangindawo $v$ Head of the Nyanda Regional Authority; Hlantlalala v Head of the Western Tembuland Regional Authority 19983 BCLR 314 (Tk)

Bhe v Magistrate, Khayelitsha 20051 SA 580 (CC)

Camps Bay Ratepayers and Residents Association v Harrison 20112 BCLR 121 (CC)

In re: Certification of the Constitution of the Republic of South Africa, 1996 199610 BCLR 1253 (CC)

Phillips v National Director of Public Prosecution 20062 BCLR 274 (CC)

MM v MN 20134 SA 415 (CC)

Mokone v Tassos Properties 20171 BCLR 1261 (CC)

Netshituka v Netshituka 20115 SA 453 (SCA)

Ramuhovhi v President of the RSA 20166 SA 210 (LT) 
Ramuhovhi v President of the RSA 20182 BCLR 217 (CC)

$S$ v Lubisi 20039 BCLR 1041 (T)

$S$ v Thunzi 201010 BCLR 983 (CC)

Sepadi v Premier of Limpopo Provincial Government 2016 JOL 34328 (GP)

Shilubana v Nwamitwa 20092 SA 66 (CC)

Sigcau v Sigcau 1944 AD 76

Van Breda v Jacobs 1921 AD 330

\section{Legislation}

Constitution of the Republic of South Africa Act 200 of 1993

Constitution of the Republic of South Africa, 1996

Recognition of Customary Marriages Act 120 of 1998

\section{Internet sources}

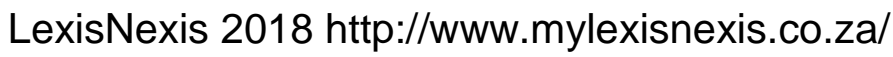

LexisNexis 2018 My LexisNexis http://www.mylexisnexis.co.za/

(subscription needed)

Women's Legal Centre 2018 http://www.wlce.co.za/about-us/

Women's Legal Centre 2018 About Us http://www.wlce.co.za/about-us/ accessed 1 October 2018

\section{List of Abbreviations}

J Comp L

J Legal Plur

RLE

U Pa L Rev

Widener LJ
Journal of Comparative Law

Journal of Legal Pluralism and Unofficial Law

Review of Law and Economics

University of Pennsylvania Law Review

Widener Law Journal 